\title{
Understanding and Practice in China National Standard-Referenced Accreditation of Medical Education from Moral and Professional Quality
}

\author{
Hong Xie, Xiongying Zhang, Juan Liu and Guangtao Xu \\ Department of Students' Affairs \\ Jiaxing University \\ Jiaxing, Zhejiang Province, P.R.China \\ xh_1968@mail.zjxu.edu.cn
}

\begin{abstract}
According to the Undergraduate Medical Education Standards of Clinical Medicine jointly issued by the Ministry of Education and the Ministry of Health in P.R.China, and combined with the first clinical medicine demonstration on the new undergraduate college proposed by the expert panel, from the perspective of students management, we proposed our operating paths and detailed steps on ideological and moral education and occupational qualities of the professional accreditation. Meanwhile, based on the weakened results during the process of accreditation, we provided targeted argument to improve the quality of medical education
\end{abstract}

Keywords- medical education; professional certification; ideological ethics; occupational qualities

\section{INTRODUCTION}

In order to further promote medical education and international integration, improve the education quality assurance system and the new Office of Undergraduate Medical Education Quality. Jiaxing University seizes the opportunity to actively seek, take the initiative to apply to the Ministry of Education clinical professional certification. Nov. 25, 2012 to 29 Medical Certification Experts conducted a site visit on Jiaxing University Medical College clinical expertise. Jiaxing University clinical professional certification was organized by the Ministry of Education eighth nationwide clinical professional certification, also organized by the Ministry of Education for the new Undergraduate College's medical Professional Certification in the first time. According to the Undergraduate Medical Education Standards (hereinafter referred to as standard), Jiaxing University Medical College clinical expertise through the certification by ministry of Education clinical professional certification working committee's deliberations and ministry of Education, Medical Education Certification Expert Committee's approval, the validity period of four years.

\section{CONNOTATIONS IN TRAINING OBJECTIVES OF IDEOLOGICAL ETHICS AND OCCUPATIONAL QUALITIES}

The Ministry of Education, the Ministry of Health jointly formulated and promulgated the standard, proposing basic requirements to undergraduates clinical medical professional education from two parts of undergraduate clinical medicine graduates should meet the basic requirements and clinical professional undergraduate education school standards in 2008, this standard was based on the international standards with Chinese characteristics, clinical medical professional education standards, was also an indicator of clinical medical professional certification. Putting forward three basic goals of ideological ethics and occupational qualities, knowledge, skills in standard in the first part of the undergraduate clinical medicine graduates should meet the basic requirements. A total of twelve specific evaluations indexed only on ideological ethics and occupational qualities of this basic task [1]. In this regard, be summed up as eight areas.

\section{A. Three Views Education}

Such as the use of course, practices, reading activities and all kinds of social practice for the world, life and values education.

\section{B. Love Culture}

As in the clinical probation and internship teaching activities, it fully reflects that "taking patients as the center" and occupation education of medical ethics of caring for the patients and for the sake of patients in the effective diagnosis and rational use of drugs, etc.

\section{Communication Arts}

As in the practice teaching requires students through the learning industry etiquette and social activities, and culturing the art in communication with patients and their families on therapy.

\section{Economic Ideas}

Such as education was establish the concept of costs and benefit through the management economics courses and experimental teaching and clinical practice.

\section{E. Lifelong Learning}

Such as through the basics of learning in school, basic skills training and experts' and teachers' lectures of frontier 
knowledge, etc to conduct the education of establishing the concept of the pursuit of excellence, continuous innovation.

\section{F. Respect for Others}

Such as through school learning, life and various student organizations to conduct the education of respecting for peers, colleagues and patients.

\section{G. Law Practice}

Such as through learning "medical disputes with law" and clinical practice conduct the education of according to the law practice, the protection of patients and their rights.

\section{H. Scientific Attitude}

Such as through scientific experiments and clinical practice develop the ideas of realistic scientific thinking and rational use of medical technology.

\section{PATHS AND MEASURES OF EDUCATION ON THE IMPLEMENTATION OF IDEOLOGICAL ETHICS AND OCCUPATIONAL QUALITIES}

Cultivation of medical talents was not just teaching the exclusive thing, quality talent assurance was a systems engineering which needs coordination with various subsystems and subsystem within the system, and that was a comprehensive educational factors inside and outside school together, which including multi-aspect what was classroom teaching, experiment teaching, clinical practice teaching, ideological and political education, student management work and social that related to the education and management functions. As a student management department, the following was what we implement the basic path and specific measures of educational objectives.

\section{A. Relying on the Red-Boat Spirit to Lead Three Views Education, Ethics First in Professional Talent}

Jiaxing University was located in the birthplace of the Chinese Communist Party in Southern Lake, the party's first national congress had the successful conclusion on a cruise ship in Jiaxing South Lake in 1921, solemnly declared the birth of the Chinese Communist Party. In Jun. 21, 2005, Jinping Xi, the Zhejiang provincial Party committee secretary of the comrades in the Guangming Daily published article Carry forward the spirit of the red boat, walk in the forefront of the times [2], pointed out that the Red-Boat Spirit was the creation of the world, dare be a person first pioneering spirit, ideals, indomitable fighting spirit, serve the public and loyal dedication to the people. Red Boat was a mother ship of the Chinese Communist Party, and the red ship was priceless to educate Chinese contemporary youth. The main function of college application of red resources educate student in three aspects. First, the Red-Boat Spirit was the training of qualified builders and successors of the red material, second, the RedBoat Spirit was the ideological weapon to calmly deal with various domestic and international challenges, and third, the Red-Boat Spirit was the theoretical source of the construction of the socialist core value system. College often organized students visit South Lake "Red Boat", visit Nanhu
Revolutionary Memorial Hall, in "Red Boat Forum" essay and theoretical research activities, the student new members to join the party oath site selection next "red boat" in South lake, through the revolutionary sites pay tribute to transfer values and positive energy, trying to make each student by the "RedBoat Spirit" baptism. In the face of the negative influence of market economy, some students had the values of the bias, emphasis on the self value, problems of moral cognition and moral behavior was divorced. Using of the precious spiritual wealth of red resources with targeted, allowing students to establish a correct world outlook, outlook on life and values. Fully reflect the mission that "Ethics for the first, emphasis on ability, the grass-roots level, the public service" in college.

\section{B. Building Healing Hands Volunteer Service Platform, Serving the Masses to Love}

Since the new office of medical undergraduate, college has been committed to create the "Skilled, Benevolence, Responsibility" as the core concept of educational environment, adhere to the medical volunteer service activities as the carrier, guide students to elite skill, thick ethics. According to the characteristics of clinical medical professional, systematically build a platform in social practice and voluntary service, organized the students use their spare time to volunteer service activities in the community, hospitals, schools, agencies and other places. Using the summer holidays time to organize students provide supporting of doctors and medicine and rural primary health care units in underdeveloped areas, combined college stage work, organize special theme of practical activities. Some student won the china youth volunteer service award (2005 annual) because of rooting mountain medical services and grassroots who was the volunteer service grassroots, grass-roots typical alumni representatives. Medical volunteer service culture has become an effective carrier of ideological ethics and occupational qualities education. First, the cultural platform practiced structures to enhance the comprehensive ability of students, and played a positive role in achievement of the goals on students' ideological ethics and occupational qualities. Students got a good education and practice which in respect for the patient and abide by the ethics of medical ethics shaping; in cherishes life, caring loving patient cultivation, in serving the masses and grassroots communication arts at exercises, respect for colleagues, in civilized etiquette of respecting for others. Students had a more in-depth understanding of the community and rural health status, to help them in the accumulation of clinical experience, at the same time that had provided necessary help in the scientific attitude of medical students training, established the concept of lifelong learning as well as the formation of economic ideas by medical volunteer services. Second, it has produced extensive influence in and out the campus. The three countryside social practice activities in summer holiday had won the university, provincial honors many times. Healing Hands as the theme of the medical culture of volunteerism has been selected as the first university campus culture boutique brand. Third, big love dedication has been continuously developing in the medical students. Through initiatives remunerated donation of hematopoietic stem cells, obligations care hero Wenhua $\mathrm{Yu}$, recycling waste materials funded vulnerable groups, raising money for the seriously ill students 
and a series of voluntary service activities, so that more young students decided to lend a helping hand to others when they were in trouble and dedication of love.

\section{Developing Second Class and Set up Scientific Attitude}

Medicine was a discipline continuous development and progressive. In the process of medical young-born on cultivation, not only requiring the students to exist medical achievements had solid accumulation, but also the students need more ability of learning independently, the development of scientific attitude and innovative consciousness. The school implemented the process which cultivating ideological and moral and professional quality goals, supported and encouraged the teachers guide students to attend the projects of science and technology such as the Student Research Training (SRT), the young-born plan, the cup of challenge. Through the open experiment, on one hand, participated in scientific and practice as the extension and expansion of theory class. On the other hand, the teachers undertook reached topic and research work were open to the students, attracted the students who were interested in it combining with the research group of teachers, formate collaborative research team. Making full use of diversified education means to cultivate the undergraduates' ability of operation, analysis and solve the problems and corrective spirits. Try our best to expanding students' occupation quality.

The combination of research projects and volunteer service was another important way to cultivate medical talents. In order to complete the SRT of Survey and construction of social medical service system in Jiaxing city home, we organized a team named "Home care, Jiaxing University advance" to carry out three countryside social practice activities in summer holiday in 2011. After the end of the practice, the team's research report was rated as outstanding research report. SRT colonel involved in the project and therefore smooth knot. Through these research practices, the students independed learning and ability to continue learning has been significantly improved, while the pursuit of excellence in lifelong learning, scientific attitude of seeking truth from facts and respect for others formed a team to create the ultimate atmosphere. In the past five years, our college won five prizes in the Cup of Challenge. In the 8th undergraduate Cup of Challenge undertaking plan contest within our province, our students group won a special grade prize. Recently, our teachers guided their students to publish more than 40 theses. The number of our medical science postgraduates increased year by year, from one student in 2008, to 6 students in 2009, and then 9 in 2010, 16 in 2011, and finally 59 students over postgraduate level in the year of 2012, and it had means that we've got into a brand new level, no matter the quantity or quality.

\section{ThINKING ABOUT PROBLEMS OF IDEOLOGICAL ETHICS AND OCCUPATIONAL QUALITIES}

\section{A. The Problems and the Reasons}

The control of medical professional certification standard, in the implementation of the training goals of ideological ethics and occupational qualities, we still have some weak links. First, according to the law practice education was not enough. Some scholars researched the medical college in the training according to the law practice consciousness problems of medical students studied, the unreasonable curriculum, teaching content lag and lack of practice three aspects [3], we also founded a similar situation. We had inspected the training program of clinical medicine specialty of 10 colleges and universities in China, there were also more or less in this aspect of the problem, there were several universities did not even set the related courses, the rest of the university curriculum with different names, learning also each were not identical, there were compulsory courses, elective courses, also have exam, there were test course, the number of hours was uneven, from at least 17 hours up to 40 hours, most schools took the teaching theory course single, only a handful universities set up 6 hours for internship and internship based in 20 hours of theoretical courses. The second, it was the concept lacks of medical economics education. The medical economy referred to the treatment of the disease process, that effectively reduced the patient pain, ensured the medical quality, medical security and strived for the maximum recovery under the premise, study on a scientific solution to save medical resources, including shorten treatment time, reduced labor intensity, reduced the medical service price, raised the efficiency of medical work, medical economy and reform of the medical and health system and closely related was still in the deepening health reform practice process at present, many policy measures was not clear yet, the school also brought inevitable effect. The reasons maybe was that the traditional medical education pays attention to the basic medical knowledge and clinical skills learning, not enough emphasis on the humanities courses. And the Chinese characteristics of the judicial system and the reform of the medical and health system was still in practice, therefore, medicine related legal, economic education started late, in the aspects of teaching content, teaching system, teaching methods and teachers.

\section{B. The Measure of Solution}

1) Focusing on the overall quality of training and continuously strengthen humanities education: With the development of medical science, medicine was no longer just a purely biological science, which will range from biological research extended to social, economic, ethical, psychological, legal, philosophy and other fields. This requires strict system of medical education must form the breadth, into the natural sciences and the social sciences in one of the multicultural education system in order to improve the overall quality of medical talented. For a long time, because the characteristics of the medical profession, medical education was often emphasis on scientific thinking, easily lead to the formation of medical students directed thinking, mechanical conservative than the lack of professional knowledge and capacity development. But, the humanities and social sciences theories and methods can develop students' horizons, develop their new way of thinking, so that they more understand to do with health care, preventive health care, ethics-related social phenomena, legal norms and economic laws, for the training of high-quality, complex medical personnel services. 
2) Build a scientific curriculum, emphasis on economic education Involving health law: As a standard clearly defined basic goal of medical personnel training, involving doctors legal and economic system was also an important part of medical education, Colleges and universities in the development of medical professional training programs should strictly implement the standard request, explicitly covered by the law and economics teaching program, set the appropriate course name and use standardized, uniform materials, In the task of teaching arrangements, it can according to the features of the school and the teachers of the actual situation to decide on teaching time, but it was necessary to further improve the doctors involved in the practice of the legal and economic aspects of education, build a scientific standardized curriculum theory and a practical teaching system.

3) Using a comprehensive universities advantages and the creation of the second class to weet the shortfall: As a comprehensive university medical profession, it should take full use of the comprehensive advantages of multi-disciplinary universities, using the open elective courses, organized the second class and other methods, to increase medical students the knowledge of laws and regulations, and economic education and training. As a student management department, we should invite experts and scholars to carry out seminars, symposiums and other forms of organization, since humanities classroom lectures were easier than cutting social hot spots and were more extensive, more novel, so it can be a useful supplement to classroom teaching and outreach. In deeper theoretical understanding, based on the legal protection of the patient to guide students to use their own interests and clear idea of practicing law and awareness, and can combine health insurance, social security and other basic health care system to learn, it requires medical students to learn not only when the patient's treatment, but also learn to be patient's accountant.

4) Expanding and encouraging social resources to enhance the practical aspects of education services: Medicine was a practical, stronger applied discipline, and medical students truly master professional skills training only through constant practice. The law and economics were also practical, applied disciplines, only through practice in order to improve and consolidate. Therefore, improving health related legal, economic, education and practice teaching, the teaching practice extends to trainee medical students, interns and other links as it should become the main task of teaching management department. But as a student management departments should actively cooperate, we should expand the social practice approach, using a variety of social resources and medical personnel training services.

\section{ACKNOWLEDGMENT}

The authors thank Dr. Jie Zhang, the vice-principal of the Jiaxing University Medical College, for finance grants support. The Teaching and Reform Planning Project of Jiaxing University (70112043)

\section{REFERENCES}

[1] Baoqing Feng, Chun Gao, "Interpret medical education standards, certification standards exploration strategy," Chongqing Medical, vol. 39 pp. 285-287, 2010.

[2] Jinping Xi, "Promote Red-Boat Spirit ahead of the times," Guangming Daily, 21.Jun.2005.

[3] Guoxiang Chen, "Mobi Jane medical students to practice law consciousness and development, "Youjiang Medical College, vol. 34, pp. 100-101, 2012. 